\title{
Kız-Kadın Kimliğinin Oluşumu ve Kadına Bakış Bağlamında Toplumsal Algıya Yön Veren Atasözleri*
}

\author{
Arş. Gör. Nilgün Aydın \\ Selçuk Üniversitesi Edebiyat Fakültesi \\ Türk Dili ve Edebiyatı Bölümü \\ naydin@selcuk.edu.tr
}

Öz

Her milletin, derinliği, eskiliği, yeniliği tartışılmaksızın sosyal hayat içinde var olan veya izleri görülen kültürel kodları bulunmaktadır. Bu kodlar, en eski çağlardan beri toplumsal algıyı yöneten ve yönlendiren gizli işlevlere sahiptir. Halkbiliminin inceleme alanına giren her ürün aslında ait olduğu milletin; hayata bakışını, algısını, felsefesini, inancını, müziğini, estetik anlayışını, topyekûn kültürel kodlarını taşıyıp yansıtmaktadır. Fakat sözel edebiyat ürünü olan atasözlerinin diğer türlere göre toplumsal kimliği inşa ve toplumsal algıya etki bağlaminda daha belirgin bir işlevi olduğu düşünülmektedir. Atasözleri, kadim zamanlardan bu yana oluşmuş tecrübelerin aktarılmasında, ataların da içinde yaşadığı sosyo-kültürel ortamın getirileri dâhilinde ortaya çıkmış ve sosyal psikolojiyi de yansıtan vazifeler üstlenmiştir. Bu açıdan bakıldığında çalışmada, atasözlerinin incelenebileceği onlarca husus arasından 'kadın' ve 'kadın algısı' eksenli bir konu tercih edilmiştir. Türk kültüründe kız (bekâret olgusu) ve kadın algısı her zaman var olmakla birlikte, anaerkil bir yapıdan ataerkil yapıya geçiş serüveninde kadının konumu ve toplumun kadın algısı değişip dönüşmüş, toplumsal hayatla birlikte farklılaşmış, bu değişim atasözlerine de yansımıştır. Buradan hareketle en eski kaynaklardan başlamak üzere atasözü kitapları, derleme kayıtları taranmış ve konuyla ilgili atasözleri belirlenmiştir. Çalışmada, elde edilen veriler, 'toplumsal bellek'-'kültürel bellek' ekseninde değerlendirilerek, atasözlerinin kız-kadın kimliğinin inşası ve algılanması bakımından taşıdığı mesajlar ile toplumun bilinçaltına etki ediş şekli çeşitli açılardan irdelenmeye çalışılmıştır.

Anahtar Kelimeler: Sözlü kültür, atasözü, kadın, toplumsal bellek, kültürel bellek.

\section{Proverbs Leading Social Perception in the Context of Perspective on Woman and Formation of Girl-Woman Identity}

\footnotetext{
Abstract

Every nation has its cultural codes that are present in their social lives. These codes have hidden functions that manipulate and manage social perception since the earliest times. Every product that belongs to the field of study of folklore actually is about the nation; reflects the gaze of life, perception, philosophy, belief, music, sense of aesthetics, and total

* Bu makale, Motif Vakfı'nın (13-15 Mart 2015) Şanlıurfa'da düzenlediği Halk Kültüründe Kadın Uluslararası Sempozyumu'nda sunulmuş, basılı olmayan bildirinin genişletilmiş şeklidir.

Gönderim Tarihi / Sending Date: 28/02/2018 Kabul Tarihi / Acceptance Date: 22/03/2018
} 
cultural codes. However, it is thought that proverbs, the product of oral literature, have a more prominent function in relation to the influence of social identity construction and social perception than the others do. Proverbs that turned over into the experiences that have occurred since ancient times, came up bearing profit of the socio-cultural environment and acting as reflecting social psychology in which the ancestors lived. Due to this reason, in the study, a topic with a focus on 'women' and 'women's perception' was chosen among the many points on which the proverbs can be examined. Thus, in Turkish culture, girls (virginity) and female perception are always present in the adventure of transition from a matriarchal structure to a patriarchal structure. The woman's position and the woman's perception have changed in the social life and this evolution has also effected the proverbs. From this point of view starting from the earliest sources, the proverbial books, compilation literature was reviewed and proverbs related to the topic were determined. In the study, all the obtained data were evaluated on the basis of 'social memory' - 'cultural memory' and it was attempted to examine how the messages carried by the proverbs affect the consciousness of the society in the development of girl-women identity.

Keywords: Oral culture, proverb, woman, social memory, cultural memory. 


\section{Gİiș}

Milletlerin de tıpkı onu oluşturan bireylerde olduğu gibi hafızaları vardır. İdrakın zamanın penceresinden süzülen yansımaları, algı boyutunda düşünüldüğünde şekillenerek vücut bulduğu iletişim ortamlarında kendine farklı çehrelerde yer edinir. İnsan algısı bireyden topluma intikal ederken, aslında yine toplumdan bireye geçenlerle hareket etmekte ve ortak belleğin oluşumuna zemin hazırlamaktadır. Her milletin kendi kültür havzasında vücut bulan, somut veya somut olmayan, kimi sahalarda bir yanıla özgün bir yanıla etkileşim içinde olup kendileştirdiği ürünleri de bu ortak belleğin aktarımındaki nesne durumundadır. Bu yönüyle düşünüldüğünde atasözlerinin özgün işleve sahip olduğunu söylemek yanlış olmayacaktır.

Geçmişten bugüne Türk kültürüne bakıldığında sözlü kültür ortamında oluşup yayılan atasözlerinin yazılı kültür ortamında varlığını güçlü bir şekilde devam ettirdiği görülmektedir. Atasözlerinin, insan ve hayatla ilgili her alanda söylenmiş olmaları, içerdikleri anlamları özlü bir şekilde aktarma özellikleri, toplumun algı ve bakış açısının kökeninde yer alan kodlarının tespit edilebilmesinde başvurulacak kaynakların başında geldiğini düşündürmektedir.

Sadece Türk halk edebiyatı alanında değil, her bağlama uygun kavram alanına sahip olması ile Türk edebiyatının genelinde yaygın bir şekilde kullanılagelen atasözleri, bu yönüyle bile taşıdığı kültürel hafızanın oluşum ve aktarım süreçlerinin irdelenmesine olan meraka kapı aralamaktadır. Çalışmanın konusu kız-kadın kimliği üzerine olduğu için, ilgili atasözlerinin bu eksende değerlendirilip tartışılmasına ve kolektif şuur altında yatan algılar ile bu algıların günümüze yansımalarının tespitine yönelik merakın izi, 'kadın'la aralanan çerçeveden sürülmeye çalışılmıştır.

Mitolojik dönemlerden bu yana Türk kültür hayatında çok önemli bir yere sahip kadınlar, atasözlerinin de konusu olmuşlardır. Bilinen ilk örnekleri Orhun Abidelerinde bulunan atasözlerinin en eski tanımı, Dîvânu Lugâti't-Türk adlı eserde bulunmaktadır. Saw olarak geçen atasözü "söz, haber, salık; mektup; risale; atalar sözü, darbımesel; kıssa, hikâye, tarihsel şeyler" olarak açıklanmaktadır (Atalay 1991: 498).

Tarihî seyir içerisinde sav yanında, mesel, darb-ı mesel olarak da anılan atasözü tanımlarını ve örneklerini pek çok kaynakta görmek mümkündür. "Nazım, nesir, her iki şekli ile eski tecrübeleri 'tam bir fikir' kompozisyonu içinde teşbih, mecaz, kinaye, tezat gibi edebi sanatların kudretinden faydalanarak süslü, kapalı olarak veya bazen açı, mecazsız hususuyla yetişecek gençlere aktaran sözler" (Elçin 2001: 626) olarak tanımlanabilen atasözleri kültür aktarımında önemli vazifeler üstlenmiştir. Ekonomiden tabiat olaylarına, sosyal olaylardan, inanış ve geleneklere kadar hayatın her alanında bilgi veren, uyaran, nasihat eden, yol gösteren, hatırlatan, denetleyen yapısıyla adeta bir kontrol mekanizması gibi çeşitli işlevleriyle toplum hayatında yer edinmiştir (Aksoy 1988: 21-22).

Türk halk hayatında dinî hükümler, hukukî prensipler gibi benimsenen atasözleri (Elçin 2001: 627) Türk kültürü içinde önemli bir yere sahiptir. Bacon'a göre bir milletin zekâsı, fikir kıvraklığı, ruhsal yetenek gücü atasözlerinden bilinmektedir (aktaran; Kurt 1991: 2). Ciddi düşünce, bellek sistemleriyle iç içe olup belleği güçlendirme zorunluluğu, söz dizimini bile koşullandırmaktadır (Ong 2007: 49). Bu düşünce, söylenişleri yalın olsa da atasözlerinde kullanılan dilin sıradan olmayıp kendine has bir yapısı bulunduğunu açıklar mahiyettedir. Atasözlerinin kendine has bu yapısı, Türk toplumunun atalarına verdiği önem ile birlikte düşünüldügünde onların söyledikleri sözlerin kıymetli olduğu bakış açısına sahip

${ }_{1}^{1}$ Ayrıntılı bilgi için bk. (Gönen 2011: 13-42). 
olmalarını sağlamıştır. Kişilerin toplumsal hayat içinde ait oldukları sosyo-kültürel çevrenin getirilerine göre yeri geldiğinde kendi düşüncelerini desteklemek adına başvurdukları atasözlerinin seçimi de aslında aktarımı yapan kişilerin algılarına ve tercihlerine göre olmaktadır. Dolayısıyla kişilerin düşüncelerini anlatmada bir nevi ataların desteğini arkasına alarak düşüncelerini aktarması, atasözlerinin hem oluşumunda hem de aktarım süreci ve sonrasında bir algı taşıdığını göstermektedir.

\section{ATASÖZLERINNDE KIZ-KADIN ALGISININ OLUŞUMU ÜZERINNE BAZI TESPITLER}

Kadınla ilgili ilk atasözü örneğine rastlanılan Dîvânu Lugâti't-Türk'te "kız" kelimesinin "pahalı" anlamına geldiği "Kalın" maddesinde verilen örnekle aktarılmıştır. "Kalın birse kız alır kerek bolsa kız alır" atasözünün anlamı: "Kalın verirse bakire gelin alır. Eğer bir şeyi istiyorsa ve ona ihtiyacı varsa onu pahalı almak zorunda kalır" şeklinde açıklanmıştır (Ercilasun-Akkoyunlu 2014: 498).

Bu örnekte "bakirelik" mefhumunun Türk toplumunda eskiden beri önemsenen bir konu olduğu anlaşılmaktadır. Toplumların bakış açılarına göre değişebilen değer yargıları, sadece sosyal hayatı değil, aslında bu hayatın parçası olan insanı ve tabii olarak insanın ortaya koyduğu ürünleri de etkilemektedir.

Türk aile hukukunun temeli ve güvencesi olarak verilen kalının o zamanki sosyokültürel çevre içinde bakireliğin önemli bir değer yargısı hâline getirmesi veya bu değer yargısından dolayı kalın verilmesi gerekliliğinin ortaya çıktığı düşünülebilir. Nitekim atasözünde geçen bakire gelin almak istenirse ona göre kalının yüksek verilmesi gerekliliği bunu açıklar niteliktedir. Burada aslında kadının sosyal statüsünün belirlenmesinin yanında bir nevi bekârete de değer biçildiği görülmektedir.

Etimolojik sözlüklerde kız, dişi çocuk; kadın ise erişkin dişi olarak geçmektedir. ${ }^{3}$ Buradan anlaşılıyor ki aslında Türkçede cinsiyet dişi ve erkek olarak ayrılmaktadır. Fakat tarihi kaynaklardan bu yana bakıldığında Türkçenin kavram alanında 'dişi' kelimesinin toplumsal hayatın şekillendirmesiyle oluşan alg1 sonucunda cinsiyeti tarifte tercih edilmediği anlaşılmaktadır. Bunun yerine hem cinsiyet adı olarak hem küçük yaştaki çocuğu anlatmada hem de bekâreti kaybolmamış veya evlenmemiş dişi insanları tanımlamakta ' $k ı z^{\prime}$ kelimesinin kullanıldığı görülmektedir. Dişi kelimesinin varlığı ise; dişi köpek, dişi kedi gibi bazı hayvanların cinsiyetini belirtmede devam etmektedir. Kız köpek, kız kedi veya kız maymun kullanımlarının olmaması bir yönüyle kız ve kadının, cinsiyet tariflerinin dışına çıkarılarak sonradan anlamlandırıldığı sonucunu ortaya çıkarmaktadır. Nitekim erkek için

\footnotetext{
${ }^{2}$ Kutadgu Bilig'de de "pahalı" ve nadir" olarak da kullanılmıştır (Arat 1979: 254).

${ }^{3}$ Nişanyan, Türkçe etimolojik sözlüğünde eski Türkçe döneminde 'kız' kelimesinin karşılığı olarak "1. kıt, nadir, 2. cimri, 3. yetişkin olmayan dişi, bakire." anlamlarını vermiş ve madde altına eklediği notta kelimeyi: " 'cömert, bol' kavramının zıddı ve kıs- fiilinin eşdeğer sıfatıdır. 'Evlenmemiş dişi, bakire' anlamı muhtemelen 'bereketsiz' fikrinden türemiştir" diye yorumlamıştır (http://www.nisanyansozluk.com/?k=k\%C4\%B1z). Tuncer Gülensoy'un “dişi çocuk” olarak tanımladığı 'kız' (2011: 522), Türk Dil Kurumu Güncel Türkçe Sözlük'te de birinci anlam olarak aynı şekilde tanımlanmıştır.

(http://www.tdk.gov.tr/index.php?option=com bts\&arama=kelime\&guid=TDK.GTS.5a6b58dd930b66.68464687).

TDK Güncel Türkçe Sözlük'te kadın kelimesi “a. 1. Erişkin dişi insan, hatun, hatun kişi, zen, erkek veya adam karşıtı. a.2. sf. Analık veya ev yönetimi bakımından gereken erdemleri olan. a.3. mec. Hizmetçi bayan. a.4. esk. Bayan." ve TDK Kişi Adları Sözlüğü'nde ise bunlara ek olarak "evlenmiş kız", "eskiden bayan anlamında kullanılan bir san" tanımları da yer almaktadır.

(http://www.tdk.gov.tr/index.php?option=com bts\&arama=kelime\&guid=TDK.GTS.5a723fd1b3e6a5.88701984 )

Tuncer Gülensoy, "Dişi cinsten erişkin insan" olarak tanımladığı kadın kelimesinin Katın<katun "kağanın eşi, hatun" olarak tanımlamıştır. <katun<kadın şeklinde dönüşmüştür (2011: 450).
} 
cinsiyet tanımlamasında böyle bir çelişkinin bulunmaması da toplumun dişi cinsiyete yüklediği kız-kadın algısının bekâretle özdeşleştirilmesi veya ayrıştırılmasını açıklar mahiyettedir. Bununla birlikte günümüzde cinsiyetin 'kadın' olarak kullanılması gerektiği görüşü hâkim bulunmaktadır ${ }^{4}$.

Günümüzde eskisi gibi olmasa da kız-kadın algısı toplum hayatında önemli bir yere sahiptir. Cinsiyetin kadın ve erkek olarak ayrıldığı gerçeğinin yadırgandığı, evlenmemiş kadınlar için formların cinsiyet kısımlarında neden $k \imath z$ yazmadığı düşünceleri, kız-kadın ikileminin bir sonucudur. Bu ikilemden olsa gerek bayan ${ }^{5}$ kelimesi bu ayrıma mahal bırakmaksızın kullanılabildiği için, cinsiyet yerine adapte edilmeye çalışılmaktadır. Nitekim halk arasında sıkça karşılaşılan "kız mısın, gelin misin?" sorusu da soran kişinin zihninde evlenmemiş kadının klz yani bakire, evlenmiş ise gelin olması gerekliliğinin sonucudur. Ayrıca, 2006 yılına kadar boşanan kişilerin nüfus cüzdanlarında dul yazması da bekâretbekârlık karmaşasının devletin politikasına etki bırakacak düzeyde olduğunu göstermesi ve toplumun değer yargılarının yaptırım gücü ve belirleyiciliğini görmek açısından ilgi çekicidir ${ }^{6}$.

Doğduğu andan itibaren mensubu olduğu sosyo-kültürel çevreye göre kendini sırasıyla; kız, genç kız, genç kadın, gelin, dul, anne, karı, avrat, hatun, hanım vs. gibi çeşitli sınıflandırmaların içinde bulan kadın, kendini bu kolektif bilince göre adapte etmeye çalışmakta ve yaşadığı çatışmaları kabul edilmiş gerçeklik algısıyla kanıksamak durumunda bırakılmaktadır. Peki, yaptırım gücü bu kadar kuvvetli olan kolektif bilinç nedir?

Kolektif bilinç; bir topluluğun tinsel ya da manevi kişilik olarak, gerek olaylar, gerekse hak ve ödevler alanında hissettiği şeylerin bütünüdür (Cevizci, 2002:179). Kendisinin ortak ahlaka duyduğu merakı çeşitli bilimlerle ve kavramlarla ele almaya çalışan Durkheim kolektiflortak bilinç kavramını geliştirmiş (Ritzer-Stepnisky 2014: 81-82) ve Bir toplumu oluşturan üyelerin ortalamasında yaşayan inanç ve duyguların tümü, kendine özgü yaşamı olan belli bir dizge oluşturur; buna ortak [kolektif] bilinç denilebilir. şeklinde açıklamıştır (Durkheim 2006: 109-110). Kuşkusuz onun tek bir organı yoktur; tanımı gereği, toplumun her yanında dağılmış durumda bulunur ama kendi başına bir gerçekliği bulunduğunu gösteren özel nitelikleri de yok

\footnotetext{
${ }^{4}$ 13.08.2010 tarihli "TDK Son Noktayı Koydu" spotuyla yapılan haberde: "Spor alanında 'Bayan mı, kadın mı sözcüğü kullanılmalı?' tartışması sürüyor. Basketbol Federasyonu'nun artık 'Kadınlar Ligi' ifadesini kullanma kararına karşın Voleybol Federasyonu 'Bayanlar Ligi'ne devam edeceğini açıklamıştı. Türk Dil Kurumu Başkanı Şükrü Haluk Akalın ise 'Doğrusu Kadınlar Ligi'dir' " açıklamasından bahsedilmiş; zamanın Türk Dil Kurumu başkanı Prof. Dr. Şükrü Haluk Akalın'ın: “'Baylar ligi' milli takımlar için 'Bay milli takımı' denilmediğini vurgulayarak, "Doğrusu elbette 'Kadınlar ligi'dir." açıklaması da bir başka husus olan bayan-kadın tartışmasını gündeme getirmiştir. (http://t24.com.tr/haber/tdk-son-noktayi-koydu,913) İnternet ortamında tarama yapıldığında "Bayan değil kadın" içerikli pek çok haberle karşılaşılmakta, bu anlamda bir bilinçlenme ve itirazın varlığından haberdar olunabilmektedir.

${ }^{5}$ Açılamalı Yeni Kelimeler Sözlüğü'nde bayan: ("bay kelimesinden tan ekiyle yapılmış gibi görünüyorsa da +an ekinin buradaki gibi bir fonksiyonu yoktur): 'Kadınların adları yerine kullanılır, hanım.' TDK 1945-74: 1. Kadınlara saygı göstermek için öz veya soyadlarının başına getirilir. 2. Kadınlara söz söylerken veya onların sözü geçerken adları yerine kullanılır./ 83-98: 1. Hanım. 2. Aynı. // AP 1966: Kadın adlarının ya da soyadlarının başına getirilen sözcük ki yazıda kısaltması (Bn.)"dir. Açıklamasından sonra Ali Püsküllüoğlu'nun bayan kelimesinin başlangıçta yanlış kabul edilip zamanla kabul gördüğünü belirttiği bir nota yer verilmiştir (Bayar 2006: 53). Mustafa Argunşah'ın kelime ile ilgili olarak “Türkçenin tarihî dönemlerinde bayan kelimesine rastlanmaz. 1930'lu yıllarda Türkçe zannedilerek alınmış, Moğolca asıllı bir kelimedir." (2017: 81) görüşüne yer verdiği yazısında bu kelimenin ortaya çıkış hikâyesi paylaşılmış, ayrıca Türkiye Türkçesindeki söz varlığı açısından kız, karı, hatun, hanım, kadın kelimeleri üzerinde durulmuştur (Argunşah 2017: 81-105).

${ }_{6}$ 29/9/2006 tarihinde Bakanlar Kurulunun kararlaştırdığı Karar Sayısı: 2006/11081 olan yazı Resmi Gazete'de yayımlanmış ve Madde 138'in (C) Fıkrasında "İlgililerin talebi halinde aile kütüklerinde kişinin medenî halini belirten "dul, boşanmış, evliliği fesh edildi ya da evliliği iptal edildi" ibareleri yerine 'Bekâr' kelimesi yazılır." şeklinde yenilenmiştir.
} 
değildir. Gerçekten de ortak bilinç, bireylerin içinde bulundukları özel koşullardan bağımsızdır; bireyler geçici o ise kalıcıdır (Durkheim 2006: 110).

Paylaşılan anlayışların, inançların ve normların genel yapısına işaret eden kolektif bilincin çok geniş ve amorf bir kavram olmasından ötürü araştırılmasının kolektif temsillerden yararlanılarak yapılabileceği belirtilmektedir (Ritzer-Stepnisky 2014: 82). Bu terimi "hem kolektif bir kavramı hem de kolektif bir gücü işaret etmek için" kullanan Durkheim, toplumun kendisi hakkında tefekkür etme biçimlerinden olduğunu belirttiği; dinî semboller, mitler ve efsaneler gibi kolektif temsil örneklerinin incelenmesi gerekliliği üzerinde durmuştur (Durkheim 1982: 40' dan aktaran; Ritzer-Stepnisky 2014: 82).

Buradan hareketle atasözlerinin de kolektif temsil örneklerinden biri olarak değerlendirilmesinin gerekliliğine dikkat çekilmektedir. Ayrıca, göz önünde bulundurulması gereken hususlardan biri; atasözlerinin genel anlamda bir milletin tamamı için geçerli olabileceği gibi, sadece bir bölgede veya küçük bir toplulukta da kabul görmüş olabileceğidir (Boratav 1978: 129). Bir diğeri ise evrensel bellek olmadiğı sadece ortak ve gruba özgü yani somut kimlikli bellek (Assmann 2001: 47) olmasından ötürü bu ürünlerin her hâliyle bellekte özgün şekilde kaldığıdır. O, kuzeyde de, güneyde de, büyük kentlerde de, küçüklerinde de, değişik mesleklerde de hep aynıdır. Bunun gibi kuşaktan kuşağa da değişmez, tersine kuşakları birbirine bağlar. Görüldü̈̆̆̈̈ gibi bireylerde ortaya çımakla birlikte, bireysel bilinçlerden apayrı bir şeydir. Toplumun ruhsal tipidir. Tipkı bireylerde olduğu gibi ama onlardan ayrı nitelikte özellikleri, var oluş koşulları ve gelişme tarzı olan bir tip (Durkheim 2006: 110). Dolayısıyla, tespit edilen örneklerin günümüzde geçerliği konusu, kent ya da kırsalda daha güçlü olup olmadığı veya hangi bölgelerde bu atasözlerinin kullanıldığından ziyade asıl vurgulanmak istenen olumsuz mesaj veren atasözlerinin varlığını devam ettirdiği ortamlarda bir şekilde kadınların bilinçaltına birtakım kodlar bıraktığıdır.

\title{
1.1. 'Kız' Kelimesi Geçen Atasözleri
}

Atasözlerinde kadının, daha doğduğu andan itibaren nasılsa evlendirileceği için çeyizinin hazırlanmaya başlanmasından fiziksel özelliklerine, evlenmesi gereken yaştan seçilirken nesebine kadar dikkat edilmesi gereken pek çok hususa değinilmektedir. Aşağıda örnekleri bulunan tüm bu sözler bir kız çocuğunun büyüyüp evlenene kadar dikkat etmesi gereken hususları belirlerken, birçok yükümlülüğü de beraberinde getirmekte ve âdeta evleneceği erkek için hazır hâle gelmesini gerekli kılmaktadır.

\begin{abstract}
Kız beşikte çeyiz sandıkta; kızı tuzla, sandığı düzle; kızın uzun saçlısı, bă̆ıı taşlısı; onbeşindeki kız, ya erdedir ya yerde; tarlayı taşlı yerden/kızı kardaşlı yerden; kızını katma akranına eşine, horoz küçükse tavuk düşer peşine; kızı kendi gönlüne bırakırsan ya davulcuya varır ya zurnacıya; kızını dövmeyen dizini döver; erken gözüyle kız almalgece gözüyle bez alma; anasına bak kızını al/kenarına bak bezini al; kızın irisini, tarlanın sulusun al; kız alan gözle bakmasın, kulak ile işitsin; bir eve bir bacalbir kıza bir koca; bir kızın doğumu babasının evinde olmalı/cenazesi kocasının evinden çıkmall; at ver dost ol, kız ver düşman ol; kız boğazı kırk boğumdur; kız dediğin kaledir, yıkılırsa çürük çaput olur; kız evladı yerine düşerse eyerli at, yerine düşmezse bir uyuz it; kızı methederek evlendirirler, gelinin iyisini gören az olur; kız satımı, hıyar satımı; kızını seven kocaya, oğlunu seven hocaya vermesin; kızın var, sızın var; kızı olan tez kocar; er bala bağ
\end{abstract}

\footnotetext{
${ }^{7}$ Metindeki atasözü örnekleri için bk. (TDK 1969); (Eyüboğlu 1973); (Aksoy 1988); (Arıkan 1994); (SÜ-THKUAM 1994);(Çobanoğlu 2004); (Gönen 2011).
} 
alması/kız bala dă̆ alması; kız evi vezir evi; kızdır nazdır bin kese azdır; kızı güzel olanın ayă̆ı yukarıda olur; kız anası köşe minderi, oğlan anası kapı yaması.

\subsection{Kadın/Avrat/Karı Kelimesi Geçen Atasözleri}

Yukarıda değinilen kız-kadın algısı sonucu atasözlerine evlenene kadar kız olarak yansıyan kadının, evlendikten sonra kadın olarak geçtiği görülmektedir. Evliliğe kadar yönlendirilen kadın, evlendikten sonra da yönlendirilmekle birlikte daha çok hakkında hüküm verici tespitler öne çıkmaktadır. Bunun yanı sıra kavram alanı açısından bakıldığında da kadın kelimesinin geçtiği metinlerin varyantları içinde çoğu kez avrat kelimesinin kullanıldığı da tespit edilmiştir.

Metinlerin büyük kısmında kadının anlatımı "koca" merkezlidir. Ana mesele kadının kocasına karşı görevleri ve nasıl iyi bir eş olunacağı temelindedir. Metinlerde, var olan algıya göre kadının olumsuz yönleri gösterilerek olumlu yönlerin yerleştirilmesinin amaçlandığı anlaşılmaktadır. Aşağıda tespit edilen atasözlerine bakıldığında durum daha iyi görülecektir.

Kadın var arpa ununu aş eder, kadın var buğday ununu taş eder; kadın erkeğin eşi, evin güneşidir; kadınsız ev susuz değirmene benzer; kadın yaşayacă̆ına kadirlik ölüm iyi; kadın kısmının saçı uzun, aklı kısa olur; kadın malı/kapı mandalı; kadın malı/eşeğin malı; deh demeden giden at, iş buyurmadan yapan evlat, beyinden önce kalkan avrat, ne murattır ne murat; kadındır evi yapan/kadındır evi yıkan; kadın erkeğin şeytanıdır; kadının sofusu, şeytanın maskarası, kadının şamdanı altın olsa, mumu diken erkektir;

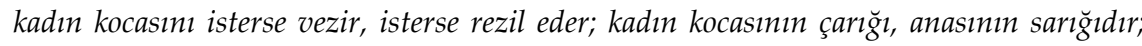
kadından olursa evliya koyma avluya; kadının biri âlâ, ikisi beladır; kadının kazdı̆̆ kuyudan su çıkmaz; kadın kocayı var sever, koca kadını să̆ sever; karı hasta olacă̆ına ben olsam, ben öleceğime karı ölse; karının kötüsü geceyi, atın kötüsü yolu uzatır; karı kocasının orospusu olmall; avrat attır gemini boş tutma; avrat nikâhla, tarla tapuyla zaptolunur; kadın döşeğinden, yiğit eşeğinden belli olur, kadını eri, peyniri deri saklar; kadının uzun saçlısı, ineğin öküz başlısı; kadın kocasına göre baş bağlar; kadın gâvurdur ama müslüman anasıdır; kadın kısmı karayazılıdır.

\section{TOPLUMSAL ALGIYA YÖN VERMESİ BAĞLAMINDA KIZ-KADIN KONULU ATASÖZLERI}

Atasözlerinin tanımından da yola çıkarak ait olduğu milletin sosyo-kültürel çevresi ile iç içeliği ve insan yaşamına etkisi açısından gizli bir yönlendirme ve denetleme mekanizması kurduğu aşikârdır. Bu bağlamda düşünüldüğünde, atasözlerinin sözel iletişim ortamında canlı kalabilme kapasitesi, kabul edilirliğine paralel şekilde geçmişten bugüne gösterdiği değişim ve dönüşüm ile bir algının sonucu olduğu çıkarımına ulaştırmaktadır.

Sosyal bir varlık olan insan yaşadığı ortamın kültürüne kayıtsız kalamamaktadır. Toplum açısından bakıldığında belirli geleneklerin, törenin, halk hukukunun da bir şekilde düzenin sağlanması açısından önem arz ettiği gerçektir fakat görünen kısmın dışında dikkat çekici husus; olumsuz anlamlı atasözleri ve toplumun genelinde olmasa bile bunu canlı tutan mekanizmanın ne olduğudur.

Yapısı itibarıyla atasözleri, 'birincil sözlü kültür ortamı'nda özenle incelenmiş bir düşüncenin korunup anımsanmasında geçerli çözüm olarak belleğe yardımcı olan, hazır, herkesin sıklıkla duyup hatırladığı ifade biçimlerinin kullanıldığı kolay hatırlanacak şekilde biçimlenmiş atasözlerinin kullanılıp belli izleklere yerleştirilmesi ile (Ong 2007: 49-50) de kuşaktan kuşağa geçen bir hafıza niteliğine bürünmüştür. Bu hafıza aktarımının, kadın ve 
içinde bulunduğu algı üzerinden değerlendirildiğinde; bilinç düzeyinde olmayan, ancak bilince ulaşabilecek her türlü bilginin, yaşantının, anının saklandığı yer (Budak 2003: 133) olan bilinçaltı düzeyinde yapılacak çalışmalara kapı aralayacak önemli ve üzerinde çalışılması gereken toplumsal kodları taşıdığı düşünülmektedir. Bununla birlikte atasözlerinin psikoloji ilmi için bulunmaz bir kaynak olduğu gerçeğinin yanında konu üzerinde bu açıdan yapılan çalışmaların sayısı var olan malzeme ile mukayese edildiğinde tatmin edici düzeyde olmadığı anlaşılmaktadır ${ }^{8}$.

Kız ve kadın ile ilgili atasözlerine bakıldığında, toplumdaki kadın algısının kadını sadece cinsiyeti itibarıyla değerlendirip ikinci sınıfa indirgediği, erkeklerden aşağıda, değersiz, evlenmese yaşayamayacağı ve evlense birçok yönden kocasına bağımlı olacağı mesajını vermektedir. Hâlbuki anaerkil süreçte Türk kadını; İslâmiyet'ten önceki Türk destanlarında, Dede Korkut boylarında at binen, ok atıp kılıç kullanan, rakibiyle savaşan, kendi işini kendi görebilen kahraman bir alp kadın tipini çizmektedir. Mitolojik anlatılarda, destanlarda, Dede Korkut boylarında kahraman tipi çizen kadınlar, Orhun Abidelerinde “... Türk milleti yok olmasın diye, millet olsun diye, babam İlteriş Kağan, annem İlbilge Hatunu göğün tepesinden tutup yukarı kaldırmıştır." (BK/D-10, Ergin 1999: 19) şeklinde kağanla birlikte anılan ve kağanın olmadığı zamanlarda ülke yönetiminde söz sahibi olacak kudrette bir tip olarak anlatılmıştır. Bunun yanı sıra anaerkil süreçte kadının varlığı başka eserler aracılığıyla da tespit edilebilmektedir. Şecere-i Türk'te:

\begin{abstract}
"Ben Ebulgazi Bahadır Han, bu günün Türk kuşă̆ına derim ki: Türk'te kadın erkekten değgerlidir, otağın asıl sahibi kadındır. Analarımız, kızlarımız, karılarımız, Tanrı'nın erkeklere erlik (olgunluk) yolundaki armağanı olan kadınlarıdır. Babam Yadigâr Han anlatırdı ki, onun çocukluğ unda kadın önden gider aşa (yemeğe) önce o el atar, miras kız çocuğa kalırmış. Daha sonra kör olası Rus ve Arap düşünceleri iki yanlı gelmişler, bize olmayan nice nice duygular getirip içimize salmışlar." denilmektedir (aktaran; Delil 1964: 389).
\end{abstract}

Gittikçe güçlenen ataerkil düzende kadınların kötülenerek toplumsal durumlarını sarsma eğilimlerinin neticesinde kadın, cinsellikle özdeşleştirilerek küçük düşülme durumuna da maruz kalabilmektedir. Saçı uzun aklı kısa atasözündeki "saçları uzun olduğu için akılları kısa olduğu söylenen kadınlara karşıt olarak; saçları kısa olduğu için erkeklerin akıllı olduğuna inanılıyor. Saçın uzun ya da kısa olmasıyla zekâ düzeyi arasında kuskusuz nesnel bir bağ yoktur." Saçı uzun aklı klsa atasözünün temelinde uzun saçlı kadınların cinsel yaşama daha yakın oldukları için akıldan eksik/kıt olacakları düşüncesi sonucu, bir yandan cinsel yaşamın, bir yandan da o cinsel yasamla özdeşleştirilen kadının kötülenmesi toplumun algısını açılar niteliktedir (Karabaş 1999: 383).

Metinler değerlendirildiğinde, kızın doğumdan itibaren evlenene kadar başına bir şey gelir endişesiyle fazlaca gözetim altında tutulduğu; bilhassa erkek kardeşi olan kızların bu gözetimden ziyadesiyle nasibini aldığı ve bu düşüncenin genel kabul gördüğü fark edilmektedir. $\mathrm{Bu}$ doğrultuda evlilik için erkek kardeşi olan kızlar tercih edilmelidir anlayışını tespit etmek mümkündür. Kız kendi seçimlerine bırakılırsa muhakkak yanlış

\footnotetext{
${ }^{8}$ Konu üzerinde çalışma yapanlardan Psikoloji Bölümü öğretim üyesi olması sebebiyle Zihniye Okray'ın, “Türk Atasözleri ve Deyimlerinde Kadın İmgesi” başlıklı makalesi ilgi çekicidir. Atasözleri ve deyimlerden hareketle Türk toplumunda kadın imgesinin nasıl sunulduğunu araştırmış ve araştırmasında içerik analizi yöntemini uygulamıştır. Konu üzerinde hazırlanmış beş makalenin özetlenmesiyle başlanan çalışmada Türk Dil Kurumu Atasözleri ve Deyimler Sözlüğünden "kocakarı, ana, dişi, kız, avrat, erkek, saç, kadın ve gelin” kelimelerinin tarandığı belirtilmiştir. Çalı̧̧mada taranan bu kelimelerin yüzdeleri tabloda gösterilmiş ve sonuç kısmında da bu veriler değerlendirilmiştir. Ayrıntılı bilgi için bk. (Okray 2015).
} 
evlilik yapacağından kesinlikle büyükler karar vermelidir ki sonra, zamanında kızı kontrol altında tutmayan aile yakınıp dövünmesin. Kız çocuğu aileye sorumluluk ve yük getireceğinden kız çocuğu olanlar erken yaşlanırlar. Erkek bağ elması gibi güzel iken kız dă̆ elması gibidir. Doğduğu andan itibaren cinsiyet ayrımı yapılan kızın, ayrıca uyması gereken kurallar vardır. Hem güzel olmalı yediklerine dikkat etmeli hem de kendine güvenilmeyip ikinci plana atıldığı bir ortamda hayatını sürdürerek bir yandan da evleneceği zamana hazırlık yapmalıdır.

Evlendikten sonra kadına dönüşen kız ise son derece maharetli olmalı, bu sefer de babasının omzundan yükünü attığı erkeğine saygı duyup, onun sözünden çıkmamalıdır. Annesinin başındaki sarık gibi iken, kocasının ayağındaki çarık gibi olma durumunu aklından çıkarmayıp her an o çarığın çıkarılabilme olasılığını, gelinlikle çıktığı eve kefenle girme korkusuyla harmanlayıp ona göre davranmalıdır. Şayet boşandı ise "alma karının dulunu / peşine gelir kulunu / senden yer senden içer / kendine yığar pulunu" (Gönen 2011: 241) kabilinden paragöz bir "dul"a dönüşüp tercih edilmemesi gerekenler listesinde olacaktır. Kadın zaten karayazılıdır. Kabullenmekten başka yapacağı bir şey yoktur.

Yukarıda yorumlanan atasözlerinin, anlamca kadını ikinci sınıf birey olarak gören bir zihniyetin ürünü olduğu anlaşılmaktadır. Çalışmada taranan atasözlerinin hepsine burada yer vermek mümkün olmamakla birlikte $k ı z, k a d \imath n$, karı, avrat ile ilgili atasözlerinin çok büyük bir kısmının olumsuz anlamda olduğu tespit edilmiştir. Türk kültüründe özellikle anaerkil süreçte ve devamlılığının görülebildiği yerlerde kadına verilen değer üst seviyededir. Fakat burada yer alan olumsuz anlamdaki atasözlerinin oluşumu ve devamlılığını bir şekilde sağlaması incelenmesi gereken önemli bir husustur. Okray, bu devamlılı̆̆ın maddi kültür unsurlarının somut olmayan kültür unsurlarına göre daha hızlı bir değişim gösterdiğinden iki öge arasındaki farklılığın artmasının kültürel gecikmeyi kaçınılmaz kıldığını belirtmiş; bundan dolayı kadın ve kadın imgelerinin de bu kültürel gecikmeden dolayı farklılıklar gösterdiğini ileri sürmüştür (2015: 100).

“Her ortak bellek zaman ve mekânla sinırlı bir gruba aittir. Olayların tümü ancak, onları hatırlayan grubun belleğinden ayrılarak gerçekleştirdikleri sosyal çevrenin düşünce yaşamındaki bağlarından çözülerek, kronolojik ve mekânsal bir şemanın ötesinde hiçbir şey kalmadığ1 zaman ortak bir tabloda toplanabilirler." (Assmann 2001: 47) şeklindeki görüş, ortak belleğin incelenmesinin o belleği oluşturan zaman ve mekân düzleminden dışarı çıkıldığında mümkün olacağını açıklamaktadır. Çünkü temel mesele toplumsal belleğin oluştuğu ortamın dışında varlığını devam ettirebilme kapasitesidir. Ortak belleğin oluşumunun açıklanması adına kültürel unsurların ortaya çıktığı tarihî, coğrafî, sosyolojik bağlamın bir arada düşünülmesi gerekir. Fakat sözlü kültürün dinamizmi ile asırlar ve nesillerin değişimi göz önüne alındığında ortak belleğin oluşum, aktarım süreci sonrasında tespit sürecinin irdelenebilmesi için oluşum ortamlarının bağlamı ve bu bağlama olan uzaklık ile toplumsal belleğin taşıdığı kültürel hafızanın içeriğini bilmek gerekmektedir. Bundan dolayı, günümüz penceresinden anaerkil zaman ve o zamandan bu yana toplumsal hayatta, ortaya çıan ürünlerde dönüşüm olduğu üzerine yorum yapılabildiği gibi, çağ gereği bir geçiş dönemi kabul edilirse şu anı ve ortaya çıkan ürünleri de top yekûn değerlendirmek, belki de zamanın epey dışına çıkıldığında mümkün olacaktır. 


\section{SONUÇ}

Her biri kendi içinde bir yaşanmışlığın sonucu olarak ortaya çıkmış atasözlerinin; tüm işlevleri, icra ve aktarım ortamları göz önüne alındığında, oluştuğu dönemde toplumun algısını yansıttığı gibi, sonrasında toplumda bir kolektif algı da meydana getirebilecek güçte olduğu görülmektedir. Çünkü insan, varlığını bir birey olarak devam ettirse de, kimliğinin oluşumu ve yaşama adapte oluş sürecinde, ait olduğu toplumun kültürel getirilerinin ve algısının etki alanındadır. Çalışmada dikkat çekilen atasözlerinin de bu etkiyi görmek açısından büyük önem taşıdığı düşünülmektedir.

Her bağlamda atasözlerinin söylenebilmesi, sözlü kültürün dışında yazılı kültürde ve Türk edebiyatının pek çok alanında kullanılması etki sahasını görmek açısından önemli olmakla birlikte; olumlu veya olumsuz bir hafıza aktarımı yaptığı aşikârdır. Bu bağlamda son yıllarda bu konuya dikkat çekilmesi, bayan-kadın, bekâr-dul, kız-kadın söylemlerindeki tartışmaların resmi mecralara yansıması ve konu hakkında düzenlemeler yapılması, görsel ve yazılı basında gündeme getirilmesi, bazı derneklerin konuya eğilmeleri ve akademik alanda yapılan çalışmaların artması hafıza aktarımının olumsuz etkilerini gösterir mahiyettedir.

Elbette Türk kadınının aile kurumu içindeki yeri, anne olarak fedakâr ve cefakâr olması, gördüğü değer, kutsal olması ile ilgili atasözleri bulunmakta ve bu sözler kadının doğuran, besleyip büyüten olmasının yanında aslında en önemlisi eğitme ve aktarma işlevinin öznesi konumunda bulunduğunu vurgulaması açısından önemlidir. Fakat çalışma kız-kadın kimliği üzerine olduğu için tespit edilen örnekler bu eksende belirlenip değerlendirilmiş ve çalışma bu çerçevede sınırlandırılmıştır.

Günümüz kadınının psikolojisi ve toplumun algısının tespit edilebilmesi için; kolektif şuur altının yansıması olan bu sözlerin kolektif bilinç ve toplumsal bellek oluşumundaki yerinin tespit edilebilmesi adına kadınlarla ilgili olumsuz anlamlı atasözlerinin önemli bir malzeme olduğu düşünülmektedir. Bu anlamda halkbilimcilerin, sosyolog ve psikologların ortaklaşa yapacakları disiplinler arası çalışmalarla konunun tespitten öteye geçirilerek tahlil ve sonuç odaklı bir mecrada ele alınabileceği kapsamlı çalışmalara duyulan ihtiyacın kabulü, konu açısından farkındalık yaratacak bakış açılarının gündeme gelmesine katkı sunacaktır. 


\section{SUMMARY}

All functions of the proverbs have emerged as true life experiences in reflecting environments as well as the perception of the society in the period of their formation. Afterwards, it is seen that they have the power of bringing a collective perception into the society. Although human beings continue their existence as an individual, they are in the domain of cultural acquisitions and perceptions of the society to which their identity belongs and in the process of adapting to life. It is believed that the proverbs that are paid attention in the study have great importance in terms of confirming this influence.

In the proverbs, somehow woman is going to get married and from the time of her birth many issues are mentioned like starting to get ready for her dowry, her physical properties, and the age she should marry and intended groom selection. Due to the girlwoman perception in the proverbs, female is mentioned as girl until she gets married ans after the marriage she is mentioned as woman.

Of course, there are proverbs about the place of the Turkish woman in the family institution, as a mother being self-sacrificing, rugged and sanctus. These words are important in emphasizing that woman is procreator, nurturer and augmentative and the most important thing in the subject is education and transfer function. However, since the study is based on girl-woman identity, the samples are identified and evaluated on this basis and the study is limited in this context.

From the perspective of the perception towards woman in society, it is believed that the proverbs which have negative meaning about women are an important material to be identified. They are the reflection of collective consciousness and social memory formation. In this sense, comprehensive studies in which folk scientists, sociologists and psychologists will work together with interdisciplinary studies will contribute to creating awareness on the subject. 


\section{KAYNAKÇA}

Aksoy, Ömer Âsım (1988). Atasözü ve Deyimler Sözlüğ̈̈ I Atasözleri Sözlüğü. Ankara: Türk Dil Kurumu Yay.

Arat, Reşit Rahmeti (1979). Kutadgu Bilig III İndeks. Ankara: Türk Kültürünü Araştırma Enstitüsü Yay.

Argunşah, Mustafa (2017). “Türkiye Türkçesindeki Kadınla İlgili Temel Söz Varlığının Tarihî Gelişimi". Uluslararası Türk Dili ve Edebiyatında Kadın Sempozyumu Bildiriler Kitabı. haz. M. Fatih Köksal vd. 4-6 Mayıs 2017. Ankara: KİBATEK Yay. 81-105.

Arıkan, Tufan [Derleyen] (1994). "Atasözü". [Kaynak kişi: Fatma Soyer, Derleme Tarihi: 10.2.1994, derleme yeri: Ödemiş/İzmir]. SÜ Türk Halk Kültürü Uygulama ve Araştırma Merkezi. kayıt no: 1098.

Assmann, Jan (2001). Kültürel Bellek. İstanbul: Ayrıntı Yay.

Atalay, Besim (1991). Dîvânu Lugâti't-Türk Dizini C. 4. Ankara: Türk Dil Kurumu Yay.

Bayar, Nevnihal (2006). Açıklamalı Yeni Kelimeler Sözlüğü̈. Ankara: Akçağ Yayınevi.

Boratav, Pertev Naili (1978). Türk Halkbilimi I-100 Soruda Türk Halk Edebiyatı. İstanbul: Gerçek Yayınevi.

Budak, Selçuk (2003). Psikoloji Sözlüğüu. Ankara: Bilim ve Sanat Yay.

Cevizci, Ahmet (2002). Paradigma Felsefe Sözlü̆̆̈̈. İstanbul: Paradigma Yay.

Çobanoğlu, Özkul (2004). Türk Dünyası Ortak Atasözleri Sözlüğü. Ankara: Atatürk Kültür Merkezi Başkanlığı Yay.

Delil, Mecdettin Ahmet (1964). “Türk Şeceresi (Şecere-i Türk) -5- Kırk Yaşına Kadar Cengiz”. Tarih Konuşuyor I (5): 389.

Durkheim, Emil (2006). Toplumsal İş Bölümü. çev. Özer Ozankaya. İstanbul: Cem Yay.

Elçin, Şükrü (2001). Türk Halk Edebiyatına Giriş. Ankara: Akçağ Yay.

Ercilasun, Ahmet Bican-Ziyat Akkoyunlu (2014). Dîvânu Lugâti't-Türk Giriş-Metin-ÇeviriNotlar-Dizin. Ankara: Türk Dil Kurumu Yay.

Ergin, Muharrem (1999). Orhun Abideleri. İstanbul: Boğaziçi Yay.

Eyüboğlu, E. Kemal (1973). Şiirde ve Halk Dilinde Atasözleri ve Deyimler. İstanbul: Doğan Kardeş Matbaacılık.

Gönen, Sinan (2011). Batı Türklerinin Manzum Atasözleri. Konya: Kömen Yayınevi.

Gülensoy, Tuncer (2011). Türkiye Türkçesindeki Türkçe Sözcüklerin Köken Bilgisi Sözlüğü C. I. Ankara: Türk Dil Kurumu Yay.

Karabaş, Seyfi (1999). “Dilbilim ile Budunbilim Arasındaki İlişki”. Bütüncül Türk Budun Bilimine Doğru. İstanbul: Yapı Kredi Yay. 377-386.

Kurt, İhsan (1991). Türk Atasözlerine Psikolojik Bir Yaklaşım. Ankara: Kültür Bakanlığı Yay.

Okray, Zihniye (2015). “Türk Atasözleri ve Deyimlerinde Kadın İmgesi”. EUL Journal of Social Sciences (VI-I) June 2015-LAÜ Sosyal Bilimler Dergisi. Haziran 2015: 94-102.

Ong, Walter J. (2007). "Sözlü Kültürün Psikodinamiği”. Sözlü ve Yazıl Kültür Sözün Teknolojileşmesi. çev. Sema Postacıŏlu Banon. İstanbul: Metis Yayınevi.

Ritzer, George-Jeffery, Stepnisky (2014). Sosyoloji Kuramları. çev. Himmet Hülür. Ankara: De ki Basım Yayın Ltd. Şti.

TDK-Türk Dil Kurumu (1969). Bölge A ̈̆ızlarında Atasözleri ve Deyimler Sözlüğü. Ankara: Türk Dil Kurumu Yay. 